\title{
PERANCANGAN SISTEM INFORMASI JADWAL PELATIHAN KARYAWAN PT. XYZ
}

\author{
Hari Purwanto \\ Universitas Dirgantara Marsekal Suryadarma \\ raldy08@gmail.com
}

\begin{abstract}
ABSTRAK
Abstrak : Pengembangan sumber daya manusia merupakan hal yang sangat penting untuk mendukung kemajuan perusahaan. Dengan pengembangan SDM pegawai akan memliki pengetahuan dan skill yang lebih baik. Salah satu pengembangan SDM yang diperlukan adalah dengan mengadakan kegiatan training. Adapun dengan kegiatan ini akan menambah kemampuan pegawai dari soft skill, Namun kegiatan ini tidak akan berjalan dengan baik, jika tidak diatur dengan penjadwalan yang sistematis. Banyak perusahaan yang menerapkan sistem penjadwalan training dengan cara manual, sehingga resiko jadwal training yang saling tumpang tindih bisa terjadi. Oleh karena itu, penulis berpendapat perlunya dirancang suatu sistem informasi penjadwalan training yang memudahkan perusahaan dalam mengatur jadwal training dengan baik. PT. XYZ adalah salah satu perusahaan yang bergerak di bidang pemeliharaan transportasi udara yang menjadi objek penelitian, dimana perushaan ini memiliki jumlah karyawan yang cukup banyak dan jadwal pelatihan yang cukup padat. Learning service adalah salah satu divisi yang memiliki tugas menangani dan menyusun jadwal pelatihan. Rancangan Sistem informasi jadwal pelatihan yang dikembangkan berbasis web, sehingga memudahkan akses pengguna yang berada di cabang. Penulis berharap hasil rancangan system informasi ini dapat membantu divisi learning service dalam menyusun jadwal pelatihan.
\end{abstract}

Kata kunci: Penjadwalan, Training, Sistem, Informasi, Web.

\section{Pendahuluan}

Dalam era global dengan perkembangan teknologi dan ilmu pengetahuan yang tumbuh pesat sekarang ini, sangat dibutuhkan sistem informasi untuk mempermudah proses pengolahan data dan pengambilan keputusan. Untuk menjalankan suatu aktivitas apapun, tak terlepas dari jadwal agar setiap kegiatan dapat terorganisir dengan baik. Penjadwalan adalah pengalokasian waktu yang tersedia untuk melaksanakan masing-masing pekerjaan dalam rangka menyelesaikan suatu proyek hingga tercapai hasil optimal dengan mempertimbangkan kebatasan-kebatasan yang ada (Abrar Husein, 2011). Dari sekian banyak teknologi informasi, sistem informasi bukanlah suatu yang baru di masa sekarang.

Kegiatan penelitian dilakukan di PT. XYZ berlokasi di Tangerang. Perusahaan memiliki sumber daya manusia dengan kemampuan atau pengetahuan mengenai bisnis terkait yang tentunya membutuhkan pelatihan lanjut agar dapat meningkatkan keahlian serta mutu kualitas karyawan. Dengan begitu, perusahaan mengadakan pelatihan pada karyawan yang dipilih dari setiap unit. Sebelum melaksanakan pelatihan, diperlukan penyusunan jadwal agar kegiatan dapat terorganisir dengan baik. 
Penelitian yang di lakukan penulis di PT. XYZ ialah untuk mengatasi masalah dalam penyimpanan, pengolahan dan penyajian data, yaitu data pelatihan, waktu mulai dan selesai pelatihan, tempat, dan instruktur. yang saat ini masih menggunakan sisem manual sebagai media penyimpanan dan penyajian. Untuk menangani permasalahan yang terjadi dibutuhkan sebuah sistem yang dapat menjadi solusi untuk permasalahan yang telah disebutkan sebelumnya.

Berdasarkan uraian diatas, maka penulis akan membahas mengenai "Perancangan Sistem Informasi Jadwal Pelatihan Karyawan PT. XYZ" sebagai judul penelitian penulis.

Dari latar belakang yang telah dipaparkan diatas, maka terdapat identifikasi masalah yaitu: Bagaimana agar perancangan sistem jadwal pelatihan karyawan pada PT. XYZ dapat mempermudah kinerja Admin?

Dengan batasan masalah Sistem yang akan dibuat hanya membahas tentang proses penjadwalan pelatihan karyawan pada PT. XYZ.

Adapun untuk tujuan penelitian ini adalah

1. Mengubah sistem manual dalam jadwal pelatihan karyawan ke dalam komputerisasi.

2. Memudahkan pihak yang bersangkutan dalam Penjadwalan pelatihan karyawan.

Dan manfaat dari penelitian ini adalah sebagai berikut :

1. Meringkas pekerjaan admin dalam menginput jadwal pelatihan.

2. Mempermudah penyimpanan data dalam penjadwalan pelatihan.
3. Meningkatkan mutu perusahaan dalam pengoprasian sistem terutama dalam menyusun jadwal pelatihan.

Dalam rangka menyelesaikan penelitian, maka penulis membutuhkan data yang berhubungan dengan topik pembahasan. Adapun metode yang penulis lakukan yaitu sebagai berikut :

1. Studi Lapangan

a) Observasi

Penulis melakukan pengamatan pada lingkungan penelitian.

b) Wawancara

Penulis melakukan wawancara untuk mendapatkan informasi serta membantu dalam pengumpulan data penelitian.

2. Studi Pustaka

Penulis membaca dan mempelajari jurnal atau artikel melalui website atau dalam bentuk buku yang memiliki keterkaitan dengan judul penulis dan di jadikan acuan dalam penelitian serta untuk melengkapi pembahasan dalam pengumpulan data pada penelitian.

\section{Tinjauan Teori}

\subsection{Sistem Informasi}

Sistem informasi adalah sistem yang dapat didefinisikan dengan mengumpulkan, memproses, menyimpan, menganalisis, menyebarkan informasi untuk tujuan tertentu. Seperti sistrm lainnya, sistem informasi terdiri atas input (data, instruksi) dan output (laporan, kalkulasi), (Sutarman, 2012: 13).

Menurut Romney dan Steinbart (2015: 3) sistem adalah rangkaian dari dua atau lebih komponen-komponen yang saling berhubungan, yang berinteraksi untuk mencapai suatu tujuan. Sebagian besar sistem terdiri dari subsistem yang lebih kecil yang mendukung sistem yang lebih besar. 
Dari definisi para ahli diatas, dapat disimpulkan sistem informasi ialah suatu sistem yang terdiri dari kumpulan sumber daya manusia, komponen sistem, yaitu software, hardware, brainware dan sumber daya melalui prosedur yang memproses informasi menjadi sebuah output yang berguna untuk mencapai suatu tujuan tertentu sesuai dengan yang diharapkan.

\subsection{Definisi Sistem}

Menurut Gordon B. Davis dalam buku Zakiyudin (2012: 1) menjelaskan bahwa sistem sebagai seperangkat unsurunsur yang terdiri dari manusia, alat, konsep, dan prosedur yang dihimpun menjadi satu unruk maksud dan tujuan bersama.

\section{Sistem adalah suatu jaringan kerja dari prosedur-prosedur yang berhubungan, terkumpul bersama-sama untuk melakukan suatu kegiatan atau tujuan tertentu (Yakub 2012: 1).}

Menurut pendapat para ahli diatas dapat di simpulkan bahwa sistem adalah kumpulan bagian-bagian atau elemenelemen yang saling berhubungan dan bekerjasama agar dapat mencapai tujuan yang sudah ditetapkan.

\subsection{Karakteristik Sistem}

Karakteristik sistem memiliki sejumlah komponen-komonen yang saling berinteraksi, bekerjasama membentuk satu kesatuan. Menurut Zakiyudin (2012: 2) suatu sistem memiliki karakter atau sifat-sifat tertentu yang mencirrikan sebagai suatu sistem mempunyai beberapa karakteristik sebagai berikut:

1. Suatu sistem mempunyai komponen-komponen sistem (component) atau subsistemsubsistem.
2. Suatu sistem mempunyai batas sistem (boundary).

3. Suatu sistem mempunyai lingkungan luar (environment).

4. Suatu sistem mempunyai penghubung (interface).

5. Suatu sistem mempunyai tujuan (goal).

\subsection{Definisi Informasi}

Informasi merupakan salah satu hal penting dalam perusahaan guna membantu dalam pengambilan keputusan sehari-hari. Banyak dari pada para ahli yang mendefinisikan pengertian informasi.

Informasi menurut Zakiyudin (2012: 5) mendefinisikan informasi sebagai data yang telah diproses sedemikian rupa sehingga meningkatkan pengetahuan seorang yang menggunakan data tersebut.

Informasi adalah data yang telah di organisasi dan telah memiliki kegunaan dan manfaat (Krismiaji 2010: $15)$.

Berdasarkan pendapat ahli di atas, dapat disimpulkan informasi ialah hasil dari pengolahan data yang memberikan makna atau arti serta nilai manfaat bagi orang yang menerimanya.

\subsection{Penjadwalan}

Penjadwalan

merupakan pengaturan waktu dari suatu kegiatan operasi. Penjadwalan mencakup kegiatan mengalokasikan fasilitas, peralatan ataupun tenaga kerja bagi suatu kegiatan operasi dan menentukan urutan pelaksanaan kegiatan operasi (Martinich, 2008). Penjadwalan dapat didefinisikan sebagai keputusan dalam penugasan dan waktu untuk memulai pekerjaan dengan menggunakan sumber daya seperti manusia, peralatan, dan fasilitas yang akan digunakan untuk suatu kegiatan. 


\begin{abstract}
Menurut L. Bethel dalam bukunya "industrial organization and management" memberikan definisi penjadwalan merupakan proses penentuan pekerjaan yang akan dilakukan. Penjadwalan adalah suatu tahapan dari suatu pengawasan produksi yang menetapkan pekerjaan dalam uruturutan yang sesuai dengan prioritasnya dan kemudian dilengkapi pelaksanaan rencana tesebut pada waktu yang tepat dengan urutan yang benar, sehingga berhubugan dengan kapan suatu pekerjaan akan dilaksanakan pada suatu bagian produksi.
\end{abstract}

\subsection{Pelatihan}

Menurut Widodo (2015: 82), pelatihan merupakan serangkaian aktivitas individu dalam meningkatkan keahlian dan pengetahuan secara sistematis sehingga mampu memiliki kinerja yang professional di bidangnya. Pelatihan adalah proses pembelajaran yang memungkinkan pegawai melaksanakan pekerjaan yang sekarang sesuai dengan standar.

Menurut Rivai dan Sagala (2011: 212), pelatihan adalah proses secara sistematis mengubah tingkah laku pegawai untuk mencapai tujuan organisasi. Pelatihan berkaitan dengan keahlian dan kemampuan pegawai untuk melaksanakan pekerjaan saat ini.

\subsection{Definisi Perancangan}

Menurut Mohamad Subhan (2012: 109) perancangan adalah proses pengembangan spesifikasi baru berdasarkan rekomendasi hasil analisis sistem. Sementara itu definisi dari Sugianto (2013: 18) perancangan sistem adalah suatu kegiatan membuat desain teknis berdasarkan kegiatan pada waktu proses analisis.
Berdasarkan definisi menurut para ahli diatas, penulis dapat menyimpulkan bahwa perancangan sistem merupakan spesifikasi baru yang menggambarkan secara rinci tahap lanjutan dari proses menganalisa sistem.

\subsection{Alat Bantu Perancangan Sistem 2.8.1 MySQL}

Menurut Anhar (2010: 21) memiliki pendapat bahwa MySQL (My Structure Query Language) adalah sebuah perangkat lunak sistem manajemen bisnis data SQL (Structure Query Languange) atau DBMS (Database Manajement System) dari sekian banyak DBMS (Database Manajement System), seperti oracle, MS SQL, Postage SQL dan lainlain.

Menurut Ahmar (2013: 11) bahwa SQL merupakan suatu sistem manajemen yang berbasis data untuk melakukan proses pengola database.

\subsubsection{PHP}

PHP (Hypertext Preprocessor) adalah bahasa pemograman website pada umumnya. PHP banyak dipakai untuk memprogram website dinamis. Tujuan utama penggunaan bahasa ini adalah untuk memungkinkan pengguna sebagai developer dapat membuat website dinamis. Program ini bisa menghubungkan antara database yang tersedia dengan tujuan dengan menampilkan data yang ada di dalam database kedalam halaman website yang akan ditampilkan oleh peramban. PHP adalah bahasa pemograman server-side script yang dirancang untuk pengembangan web (Welling \& Thomson, 2009).

\subsubsection{HTML}

HTML singkatan dari Hypertext Markup Language yaitu sebuah bahasa markup yang digunakan untuk membuat 
halaman website, menampilkan berbagai informasi di penjelajah dan formating hypertext sederhana yang ditulis kedalam berkas format ASCII (American Standart for Information interchange) agar dapat menghasilkan wujud yang terintegrasi (Meloni, 2012).

\subsection{Alat Bantu Sistem}

\subsubsection{UML (Unified Modeling Laguage)}

Menurut Rosa dan Shalahuddin (2014: 133), memiliki pendapat bahwa UML (Unified Modeling Laguage) adalah salah satu standard bahasa yang banyak digunakan di dunia industri untuk mendefinisikan requirement, membuat analisa dan desain, serta menggambarkan arsitektur dalam pemograman berorientasi objek.

Menurut Rosa dan Shalahuddin (2014: 155) UML (Unified Modeling Laguage) memiliki diagram-diagram yang berorientasi objek, diantara nya sebagai berikut :

\section{Use Case Diagram}

Use Case Diagram merupakan pemodelan untuk melakukan (behaviour) sistem informasi yang akan dibuat. Use Case digunakan untuk mengetahui fungsi apa saja yang ada didalam sebuah sistem informasi dan siapa saja yang berhak menggunakan fungsi-fungsi itu.

\section{Activity Diagram}

Activity Diagram menggunakan workflow (aliran kerja) atau aktifitas dari sebuah sistem atau proses bisnis atau menu yang ada pada perangkat lunak. Perlu diperhatikan bahwa diagram aktifitas menggambarkan aktivitas sistem bukan apa yang dilakukan aktor, jadi aktifitas yang didapat dilakukan oleh sistem.

3. Class Diagram

Class diagram menggambarkan struktur sistem dari segi pendefinisian kelas-kelas yang akan dibuat untuk memnbangun sistem. Kelas memiliki apa yang disebut atribut dan metode atau operasi.

4. Sequence Diagram

Diagram sequence menggambarkan objek pada use case dengan mendeskripsikan waktu hidup objek dan message yang diterima dan dikirimkan antar objek. Untuk menggambarkan diagram sekuen maka harus diketahui objek-objek yang terlibat dalam sebuah use case beserta metode-metode yang dimiliki kelas yang diinstansiasi menjadi objek itu.

5. Deployment Diagram

Menurut Sukamto dan Shalahludin (2014:154) pada diagram deployment menunjukan konfigurasi komponen dalam proses eksekusi aplikasi. Diagram deployment juga dapat digunakan untuk memodelkan halhal seperti sistem tambahan dan sistem client/server.

7. State Diagram

Menurut Satzinger et el (2010:260) mengungkapkan bahwa state atau kondisi dari sebuah objek yang terjadi selama masa hidupnya memenuhi beberapa standar, menjalankan kegiatan, atau menunggu peristiwa.

\subsubsection{Data Flow Diagram (DFD)}

Pengertian Data Flow Diagram (DFD) menurut Jogiyanto Hartono, 2005:701 adalah "Diagram yang menggunakan notasi simbol untuk menggambarkan arus data system".

DFD sering digunakan untuk menggambarkan suatu sistem yang telah ada atau sistem yang baru yang akan dikembangkan secara logika dan menjelaskan arus data dari mulai pemasukan sampai dengan keluaran data tingkatan diagram arus data mulai dari 
diagram konteks yang menjelaskan secara umum suatu sistem atau batasan sistem dari level 0 dikembangkan menjadi level 1 sampai sistem tergambarkan secara rinci. Gambaran ini tidak tergantung pada perangkat keras, perangkat lunak, struktur data atau organisasi file.

Menurut Jogiyanto Hartono, tahun 2005 dalam bukunya Basia Data ada beberapa simbol digunakan pada DFD untuk mewakili :

1) Entitas

Eksternal(External

Entity)

Entitas Eksternal(external entity) merupakan entitas(entity) di lingkungan luar sistem yang dapat berupa orang, organisasi, atau sistem lain yang berada pada lingkungan luarnya yang memberikan input atau menerima output dari sistem.

2) Proses (Process)

Proses (process) menunjukan pada bagian yang mengubah input menjadi output, yaitu menunjukan bagaimana satu atau lebih input diubah menjadi beberapa output. Setiap proses mempunyai nama, nama dari proses ini menunjukan apa yang dikerjakan proses.

3) Arus Data (Data Flow)

Arus Data (data flow) di DFD diberi simbol suatu panah. Arus data ini mengalir di antara proses, simpan data dan kesatuan luar. Arus data ini menunjukan arus dari data yang dapat berupa masukan untuk sistem atau hasil dari proses sistem.

4) Simpanan Data (Data Store)

Data Store merupakan simpanan dari data yang dapat berupa suatu file atau database pada sistem komputer.

\subsubsection{Flowchart}

Community (2011: 16), Flowchart adalah simbol-simbol pekerjaan yang menunjukan bagan aliran proses yang saling terhubung. Jadi, setiap simbol flowchart melambangkan pekerjaan dan instruksinya. Simbolsimbol flowchart adalah standar yang ditentukan oleh America National Standart Inc.

\subsection{Basis Data}

Istilah basis data mengacu pada koleksi dari data-data yang saling berhubungan. Menurut James Martin dalam buku Nur Elfi Husda (2012:151), basis data ialah suatu kumpulan data terhubung yang disimpan secara bersamasama pada satu media, tanpa mengatap satu sama lain atau tidak perlu suatu kerangkapan data dengan cara-cara tertentu sehingga mudah untuk digunakan atau di tampilkan kembali, dapat digunakan untuk satu atau lebih program aplikasi secara optimal, dan dapat disimpan tanpa megalami ketergantungan pada program yang akan menggunakannya, serta disimpan sedemikian rupa sehingga penambahan, pengambilan dan modifikasi data dapat dilakukan dengan mudah dan terkontrol.

\section{Analisa Sistem Berjalan \\ 3.1 Prosedur Berjalan}

Berikut rangkaian prosedur bisnis yang berjalan saat ini beserta gambaran Activity Diagram :

1. Manajer LCU merekrut karyawan yang akan di ikut sertakan dalam pelatihan

2. Data peserta yang sudah di rekrut di berikan pada unit Learning Service.

3. Setelah itu dibuatkan ATP (Annual Training Pogram).

4. ATP yang sudah dibuat di uraikan kembali menjadi jadwal pertahun. 
5. Jadwal yang sudah di susun selama setahun di uraikan kembali menjadi jadwal bulanan.
6. Jadwal bulanan yang telah terurai di input untuk di jadikan laporan pada Manajer Unit.

7. Manajer Unit menerima dan mengetahui jadwal pelatihan.

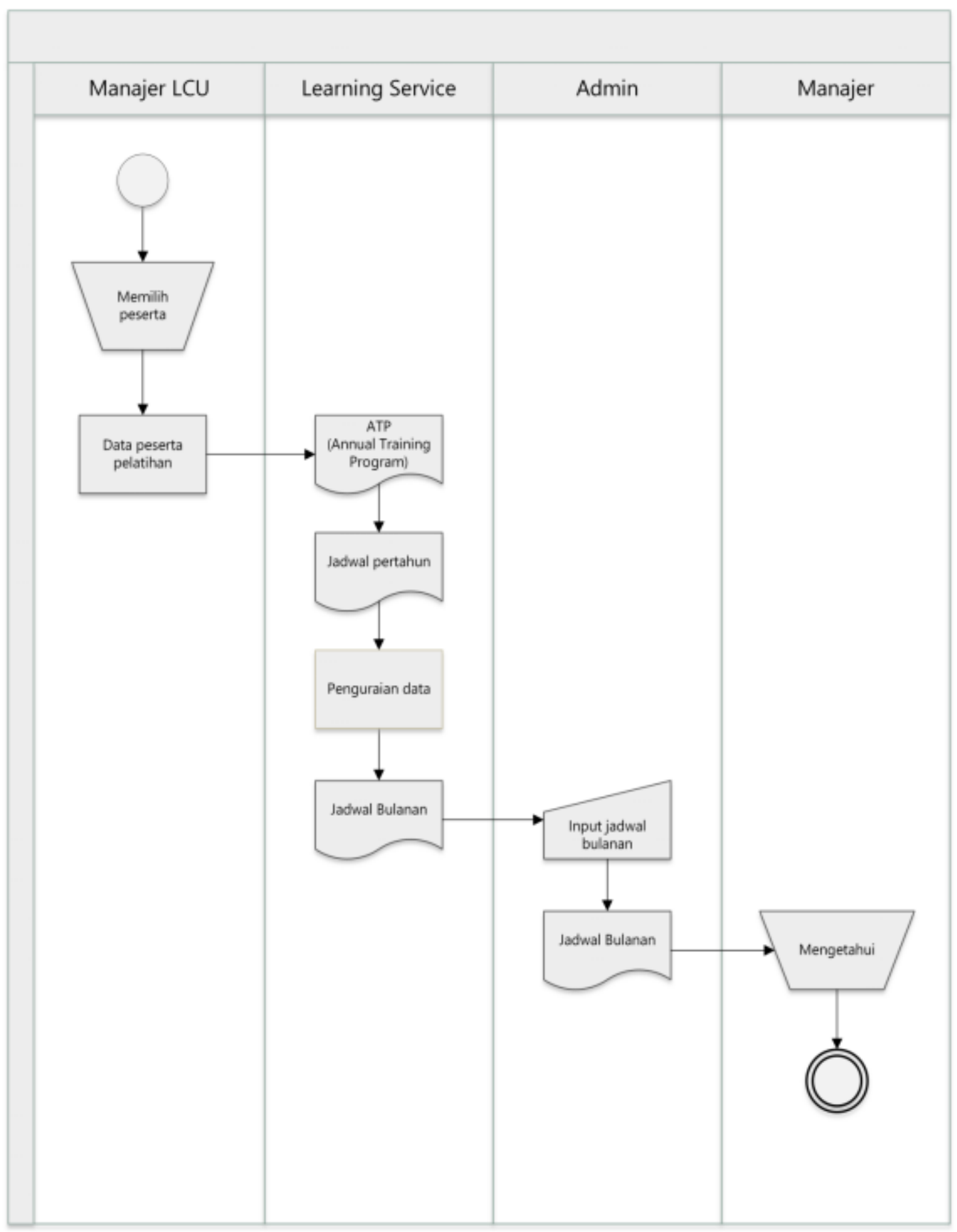

Gambar 3.1 Prosedur berjalan 


\subsection{Diagram Konteks}

Diagram Konteks adalah diagram yang menggambarkan hubungan antara entitas eksternal dengan sistem. Dimana data yang diinputkan oleh bagian entitas eksternal dengan sistem. Dimana data yang diinputkan oleh bagian entitas eksternal akan menghasilkan laporan yang diinginkan oleh eksternal tersebut. Untuk lebih jelasnya dapat dilihat pada gambar berikut:

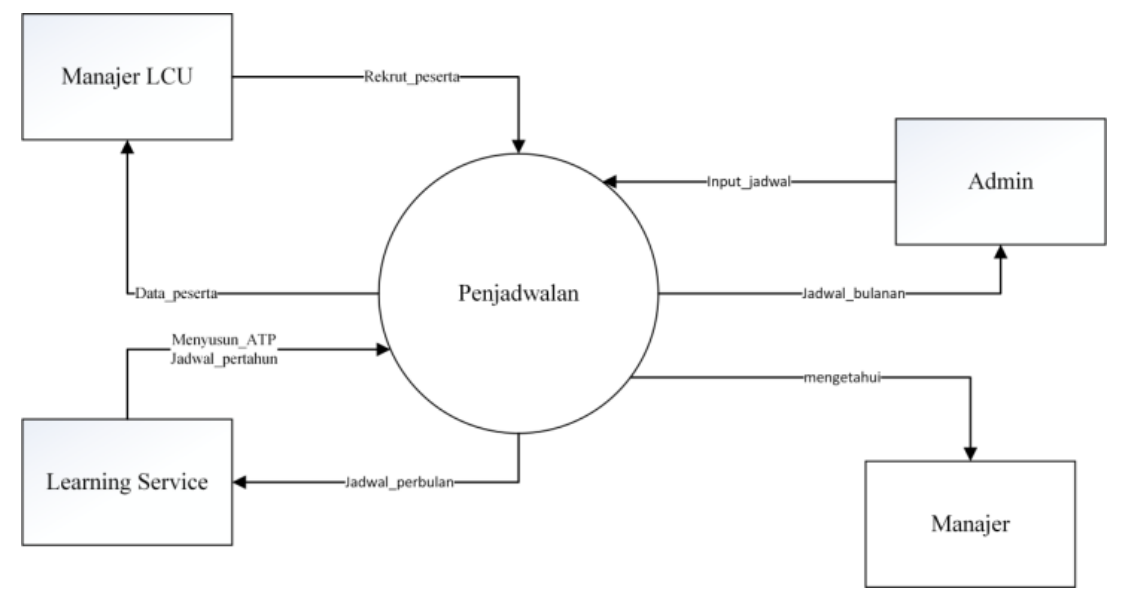

Gambar 3.2 Diagram Konteks Sistem Berjalan

Proses penjadwalan pada PT.XYZ yang sedang berjalan ialah sebagai berikut.

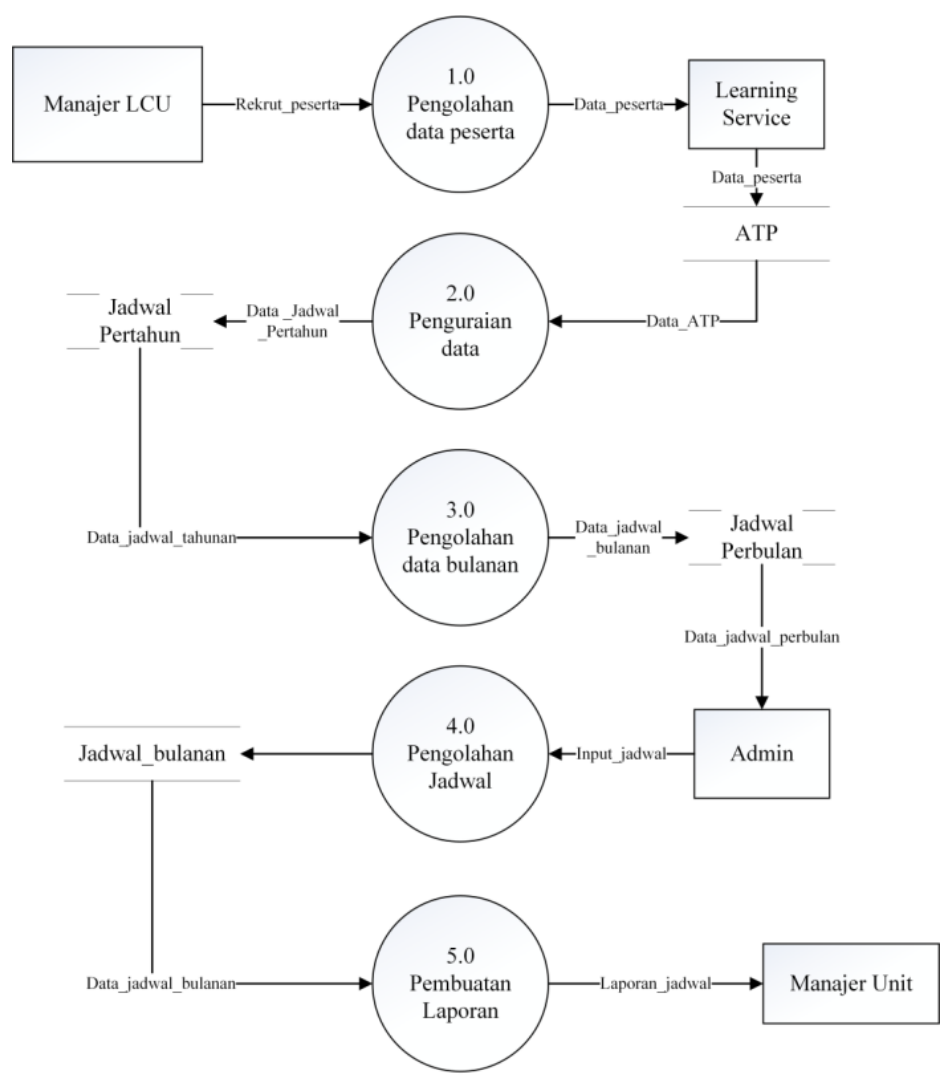

Gambar 3.2 Data Flow Diagram 
1. Proses 01 : Dalam proses ini menjelaskan alur manajer LCU yang merekrut karyawan untuk di jadikan peserta pelatihan. Data_Peserta yang ada di proses dan di berikan pada learning service sebagai penyelenggara dan penyedia pelatihan.

2. Proses 02 : Data peserta yang telah ada di Learning Service di buat menjadi ATP (Annual Trainning Program). Data peserta yang sudah di jadikan data ATP di urai menjadi data jadwal pertahun.

3. Proses 03 : Data jadwal pertahun di olah dan di jadikan Data jadwal bulanan dan di berikan pada admin untuk di input dalam Ms.Project.

4. Proses 04 : admin meng-input jadwal dalam Ms.project sebagai media penyimpanan dan penyajian.

5. Proses 05 : admin membuat laporan jadwal untuk Manajer Unit sebagai pihak yang mengetahui jalannya pelatihan.

\subsection{Analisa Non Fungsional}

Dalam mengoprasikan rancangan sistem informasi membutuhkan beberapa perangkat lunak, serta untuk mengoprasikan rancangan sistem informasi ini dibutuhkan beberapa perangkat keras, berikut spesifikasi perangkat keras dan spesifikasi perangkat lunak yang dibutuhkan.

A. Spesifikasi Perangkat Keras

Operating System : Window 8 pro 64bit (6.2, build 9200)
Processor : Intel

(R)

Celeron(R) CPU N2840 @ 2.16GHz

Memory : 2048MB RAM

B. Spesifikasi Perangkat Lunak

- Operating System : Windows 7

- Web Browser : Mozila Firrefox, Crome (Rekomendasi)

- Database phpMyAdmin

- Xampp : Versi 2.6 sebagai alat bantu web system

\subsection{Permasalahan Sistem Berjalan}

Melalui wawancara dan observasi yang di lakukan oleh penulis, input pelatihan karyawan perbulan masih menggunakan Microsoft Project sebagai proses pengolahan, penyimpanan dan penyajian data. Akibatnya data menjadi terpisah pisah dan dengan menggunakan manual bila terjadi error pada data maka sudah tidak ada lagi salinan data lagi. Untuk itu diperlukannya penyimpanan dengan DBMS.

\section{Analisa Perancangan Sistem 4.1 Rancangan Sistem Usulan 4.1.1 Use Case}

Use case diagram (diagram use case) adalah diagram yang menyajikan interaksi antara use case dan aktor. Dimana aktor dapat berupa manusia, peralatan, atau sistem lain yang berinteraksi dengan sitem yang sedang dibangun. Use case menggambarkan fungsionalitas sistem atau persyaratanpersyaratan yang harus dipenuhi sistem dari pandangan pemakai (user), bukan berdasarkan alur sebuah kejadian. 


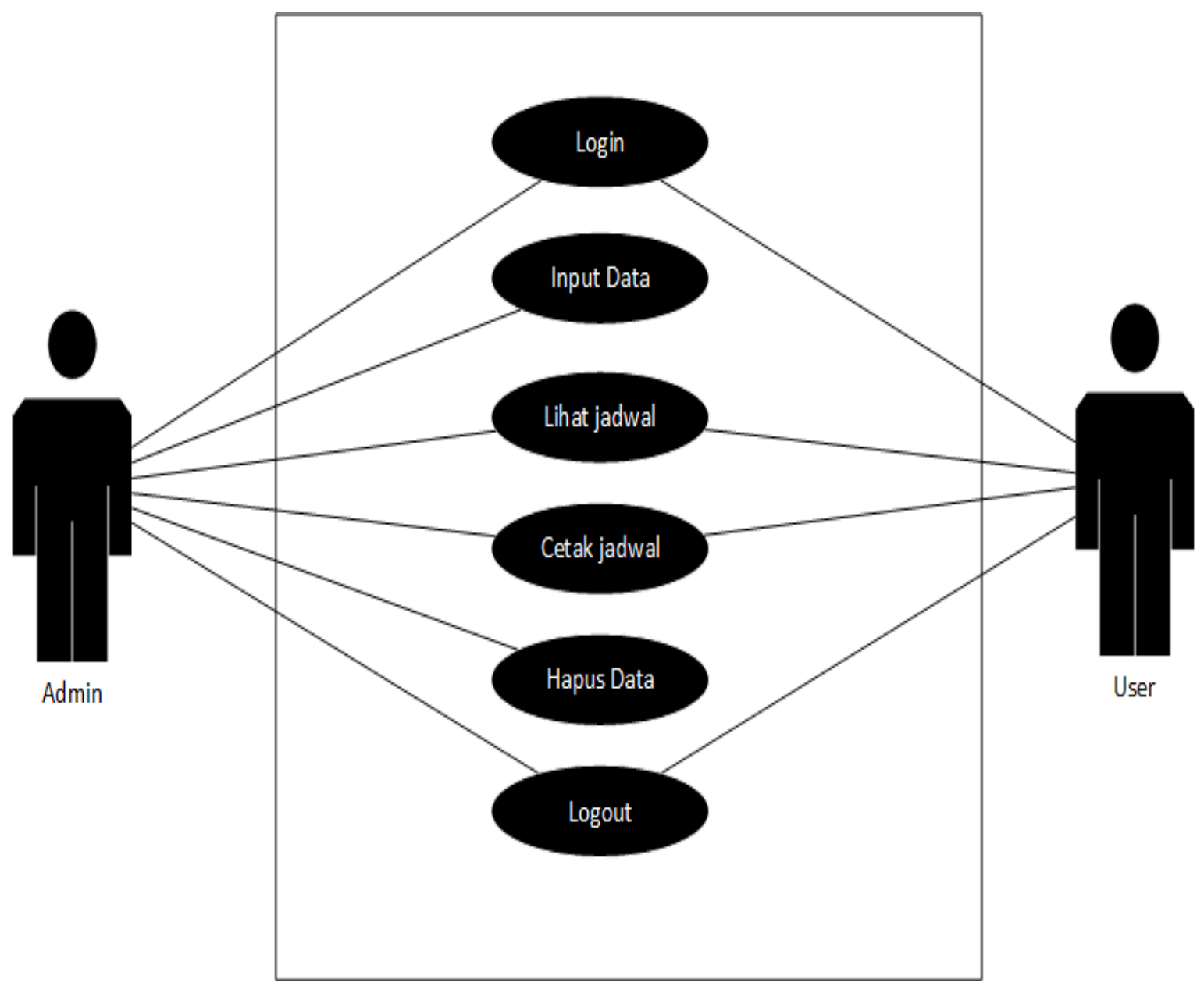

Gambar 4.1 Use case usulan

Tabel 4.1 Deskripsi Use Case

\begin{tabular}{|l|l|l|}
\hline \multicolumn{1}{|c|}{ Aktor } & \multicolumn{1}{c|}{ Nama Use Case } & \multicolumn{1}{c|}{ Deskripsi } \\
\hline Admin, User & Login & Untuk mengakses sistem \\
\hline Admin & Input data & Memasukan data jadwal \\
\hline Admin,User & Lihat jadwal & Menampilkan jadwal \\
\hline Admin, User & Cetak Laporan & $\begin{array}{l}\text { Menampilkan hasil Data } \\
\text { yang akan di cetak. }\end{array}$ \\
\hline Admin & Hapus data & $\begin{array}{l}\text { Menghilangkan data yang } \\
\text { salah atau tidak } \\
\text { diinginkan. }\end{array}$ \\
\hline Admin, User & Logout & Untuk keluar dari sistem \\
\hline
\end{tabular}




\subsection{2}

\section{Activity Diagram}

Activity Diagram (diagram aktivitas) menggambarkan aliran fungsionalitas dari sistem baru dibuat. Dalam diagram ini akan digambarkan aliran aktivitas dalam sistem baru, yang bertujuan untuk mengetahui alur proses pada sistem yang diusulkan.

\subsubsection{Activity Diagram User}

Berikut rancangan usulan dari activity diagram user beserta penjelasannya.

1. User masuk dalam tampilan login.

2. User memasukan username dan password.
3. Sistem akan memeriksa apakah username dan password benar atau tidak.

4. Jika benar maka sistem akan menghubungkan ke manu utama, namun jika salah maka sistem akan kembali pada menu login.

5. Setelah berhasil masuk, user dapat memilih menu lain, di dalam sistem ini user dapat memilih menu schedule.

6. Sistem memberikan tampilan sesuai dengan yang di minta user.

7. Dalam tampilan form schedule ini user dapat mencetak hasil tabel sebagai laporan.

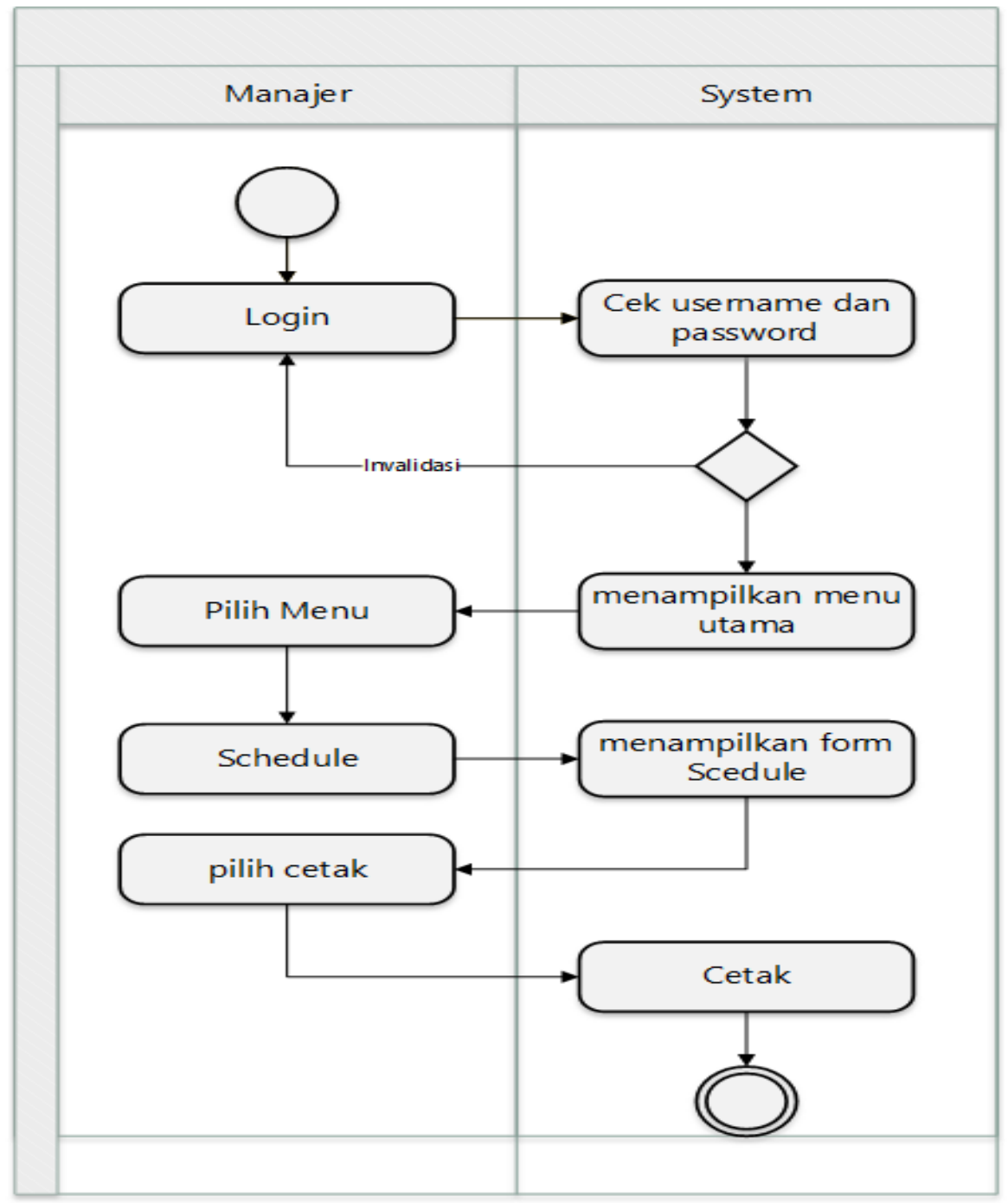

Gambar 4.2 Activity Diagram User 


\subsubsection{Activity Diagram Admin}

Berikut rancangan usulan dari activity diagram user beserta penjelasannya.

1. Admin masuk dalam tampilan login.

2. Admin memasukan username dan password.

3. Sistem akan memeriksa apakah username dan password benar atau tidak.

4. Jika benar maka sistem akan menghubungkan ke manu utama, namun jika salah maka sistem akan kembali pada menu login.

5. Setelah berhasil masuk, admin dapat memilih menu input training.

6. Setelah sistem menampilkan form input training, admin memasukan data jadwal pelatihan.

7. Admin pilih button submit, lalu sistem menampilkan tabel data jadwal.

8. Admin dapat pilih button print untuk cetak atau simpan laporan jadwal.

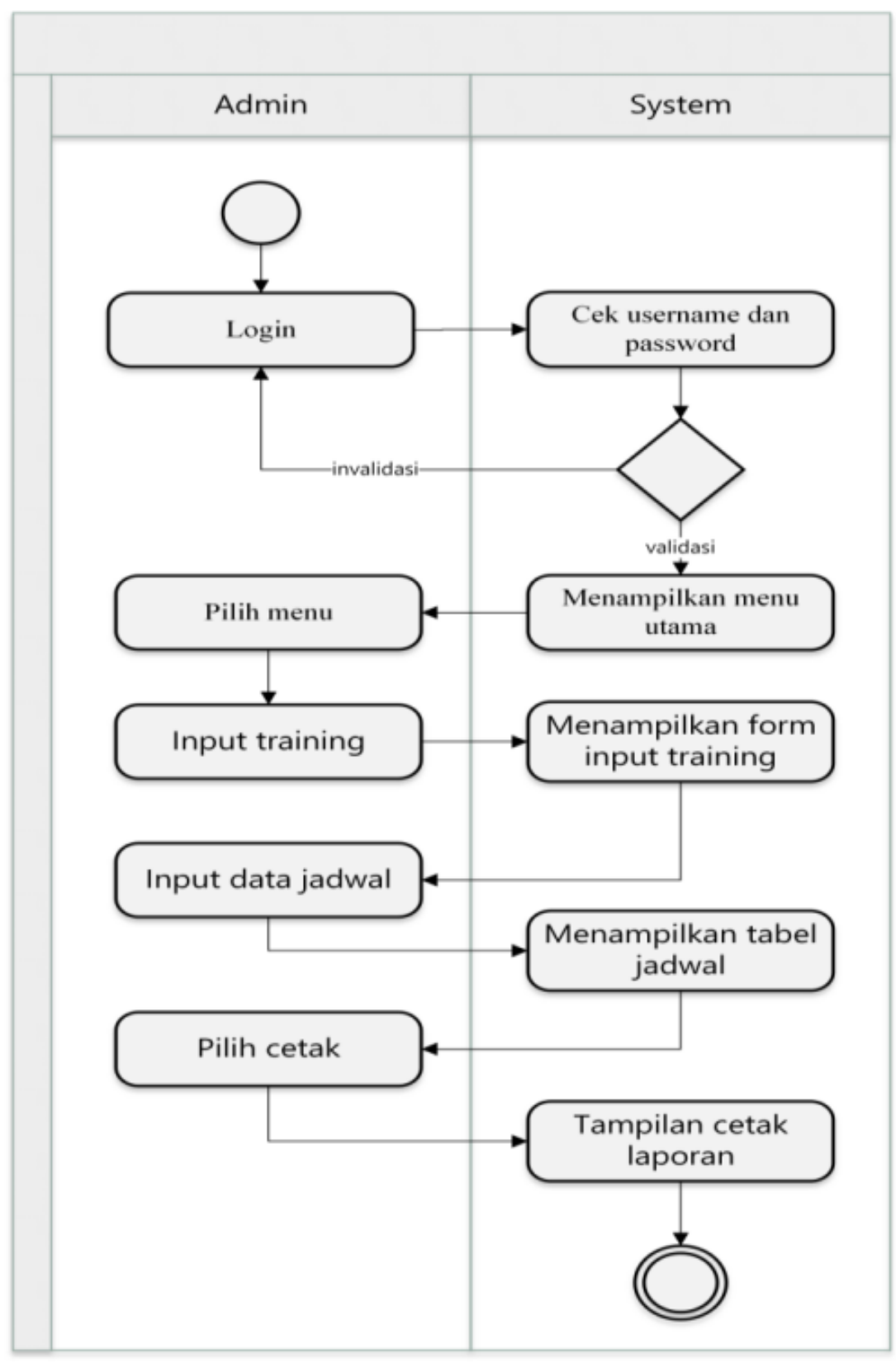

Gambar 4.3 Activity Diagram Admin 


\subsubsection{Sequence Diagram}

Dalam diagram yang

digambarkan menunjukan interaksi antar objek yang mengindikasikan komunikasi antara objek-objek tersebut. Berikut Sequence Diagram Sistem Jadwal Pelatihan Karyawan pada PT.XYZ:

\subsubsection{Sequence Diagram Login Admin}

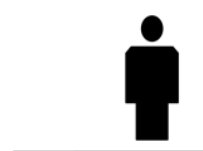

\section{Admin}

\section{Form Login}

Database
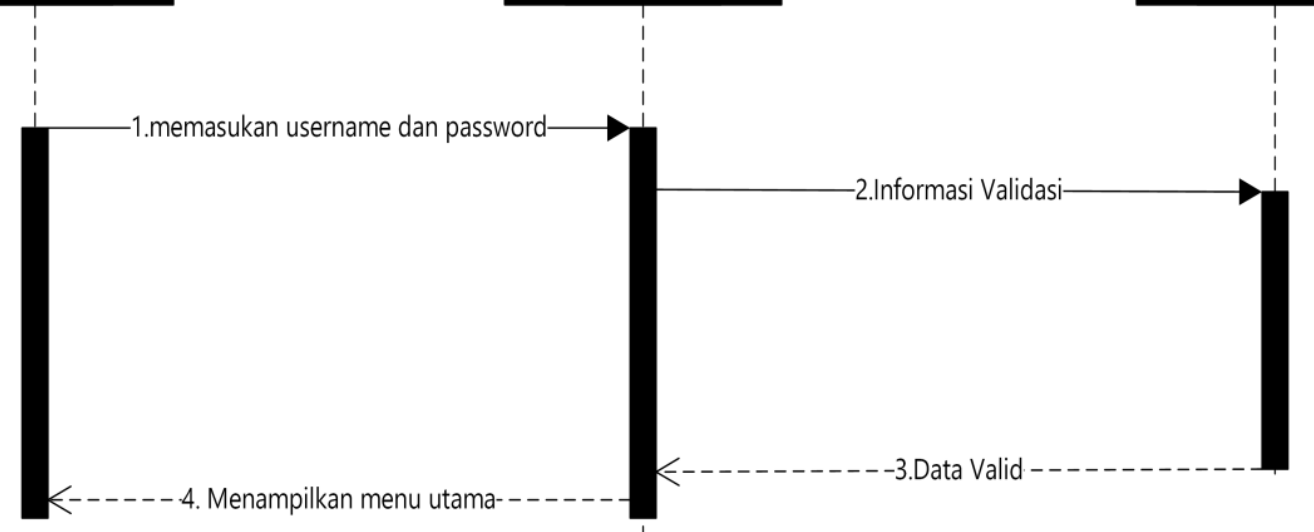

Gambar 4.4 Sequence Diagram Login Admin

\subsubsection{Sequence Diagram Input}

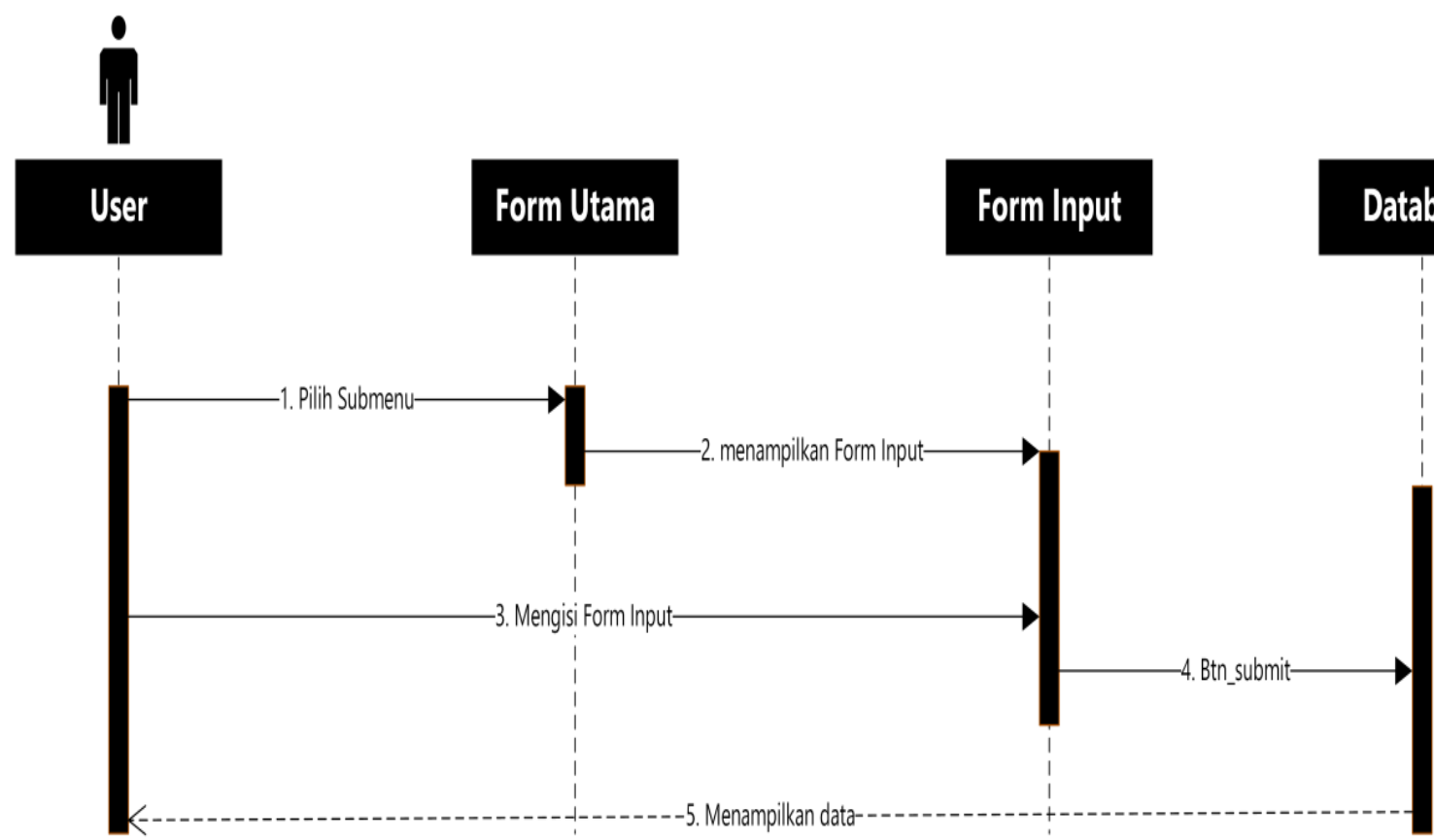

Gambar 4.5 Sequence Diagram Input 
4.1.3.3 Sequence Diagram Cetak

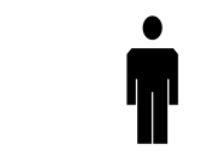

Admin

Tabel Jadwal

Cetak Jadwal

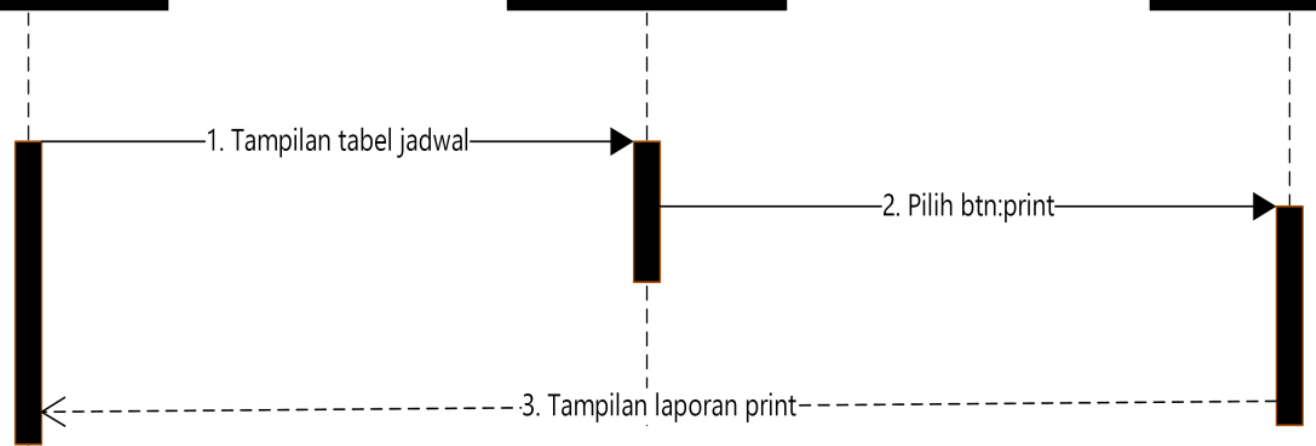

Gambar 4.6 Sequence Diagram Cetak

\subsubsection{Sequence Diagram Login User}

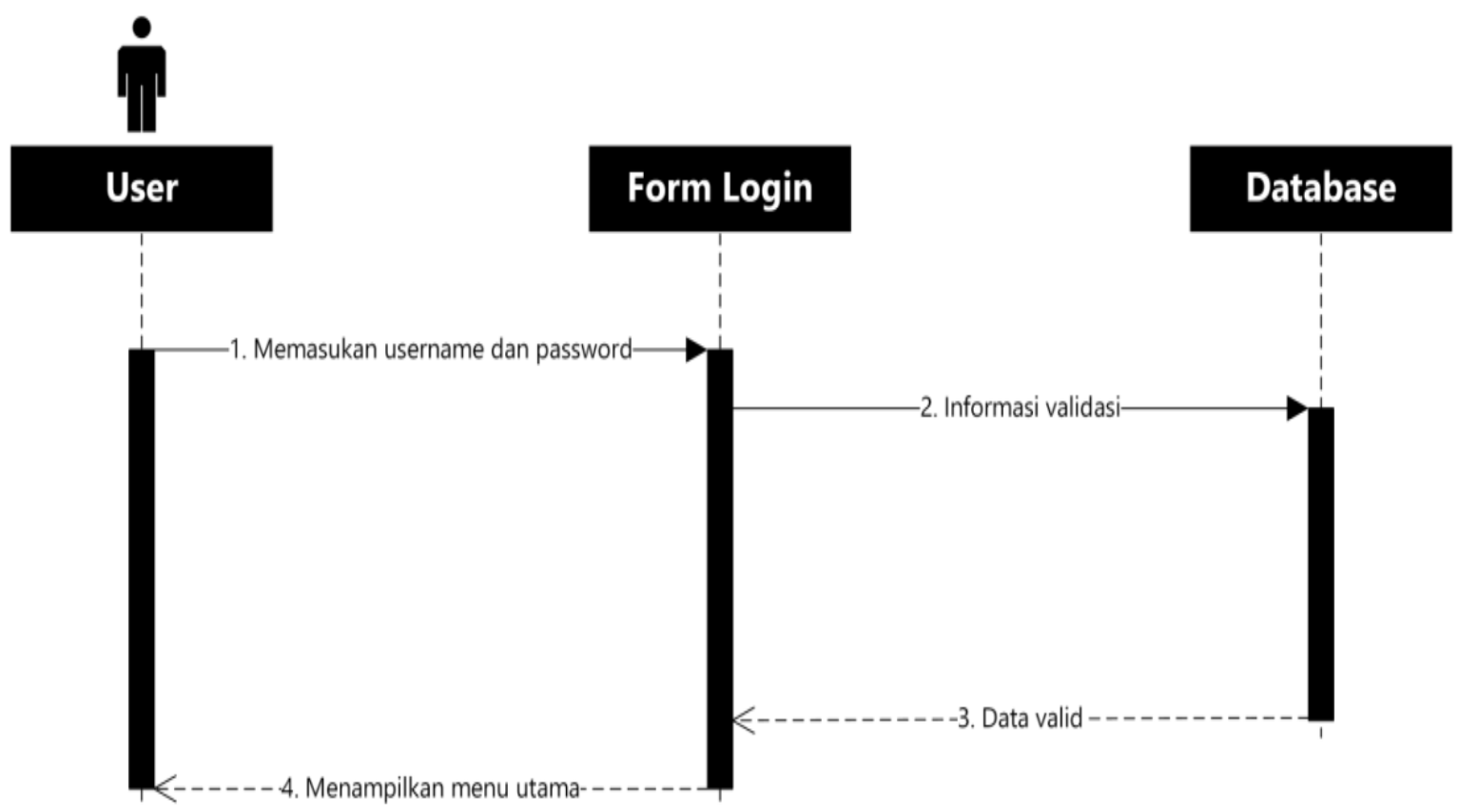

Gambar 4.7 Sequence Diagram Login User

\subsubsection{State Diagram}

Pada diagram ini mendeskripsikan perilaku sistem dan mendeskripsikan semua kondisi yang mungkin muncul sebagai sebuah objek. Bagian aktivitas dari simbol state menggambarkan aktivitas objek yang akan dilakukan selama dalam state. 


\subsubsection{State Diagram Admin}

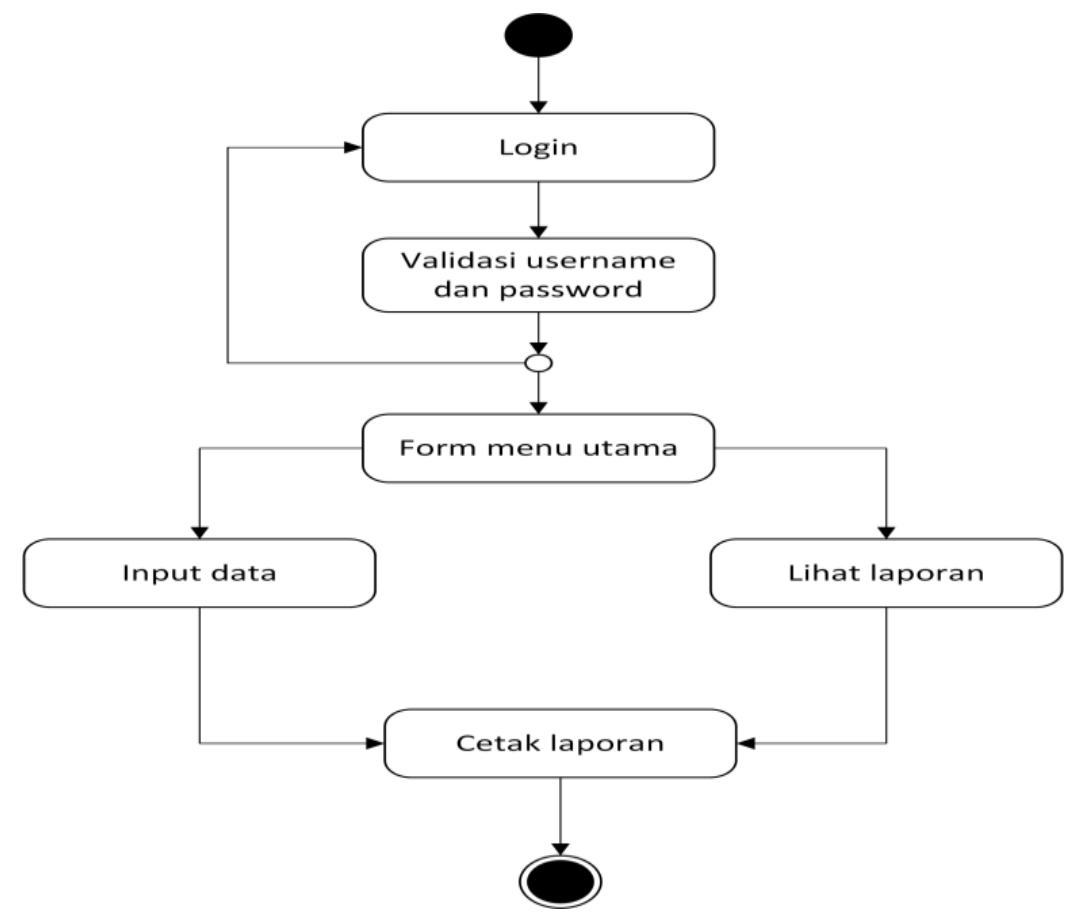

Gambar 4.9 Admin State Diagram

\subsubsection{State Diagram User}

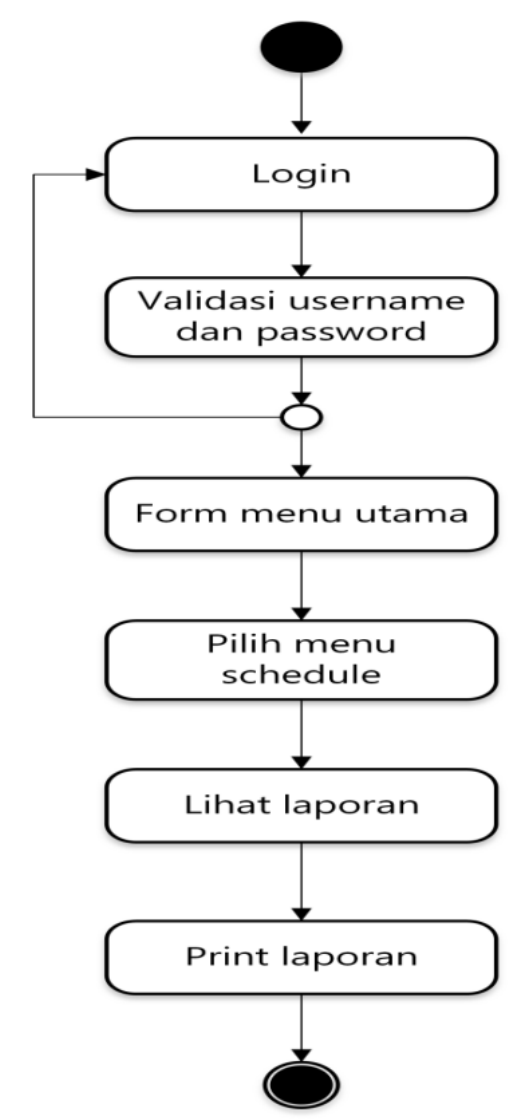

Gambar 4.10 User State Diagram 


\subsubsection{Component Diagram}

Pada diagram ini menggambarkan alokasi semua class dan objek kedalam komponen dalam desain fisik sistem software termasuk pengaturan dan kebergantungan antar komponen software.

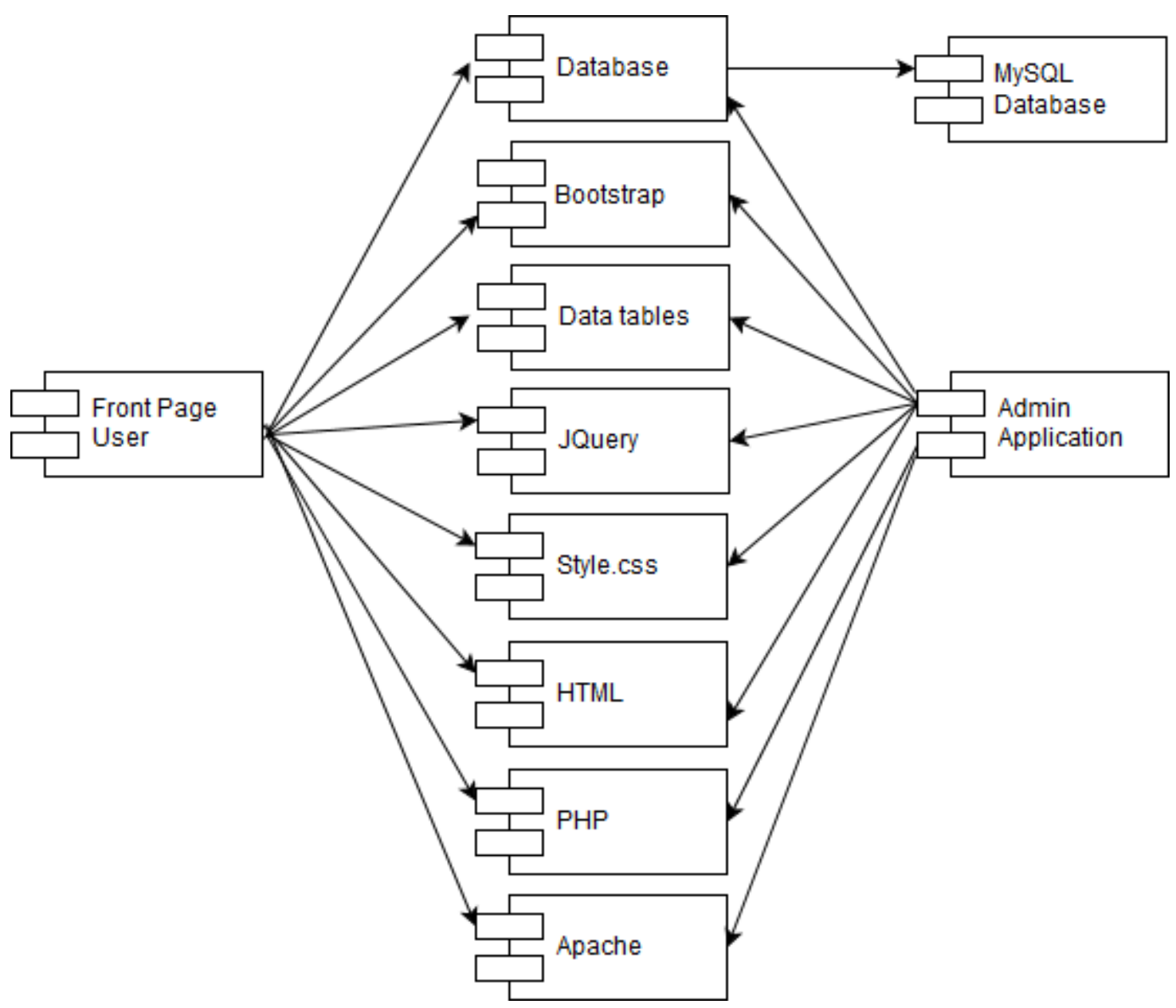

Gambar 4.11 Component Diagram

\subsubsection{Deployment Diagram}

Pada bagian diagram ini menunjukan bagian-bagian software yang berjalan pada bagian hardware yang dibuat untuk mengimplementasikan sebuah sistem dan ketrerhubungan antara komponen-komponen hardware tersebut.
Dalam penggambaran struktur fisik sebuah aplikasi yang melibatkan perangkat, baik perangkat lunak maupun perangkat keras yang dapat di sebut node dan menunjukan bagaimana kedua komponen ini dapat bekerja sama akan digambarkan dengan diagram deployment. 


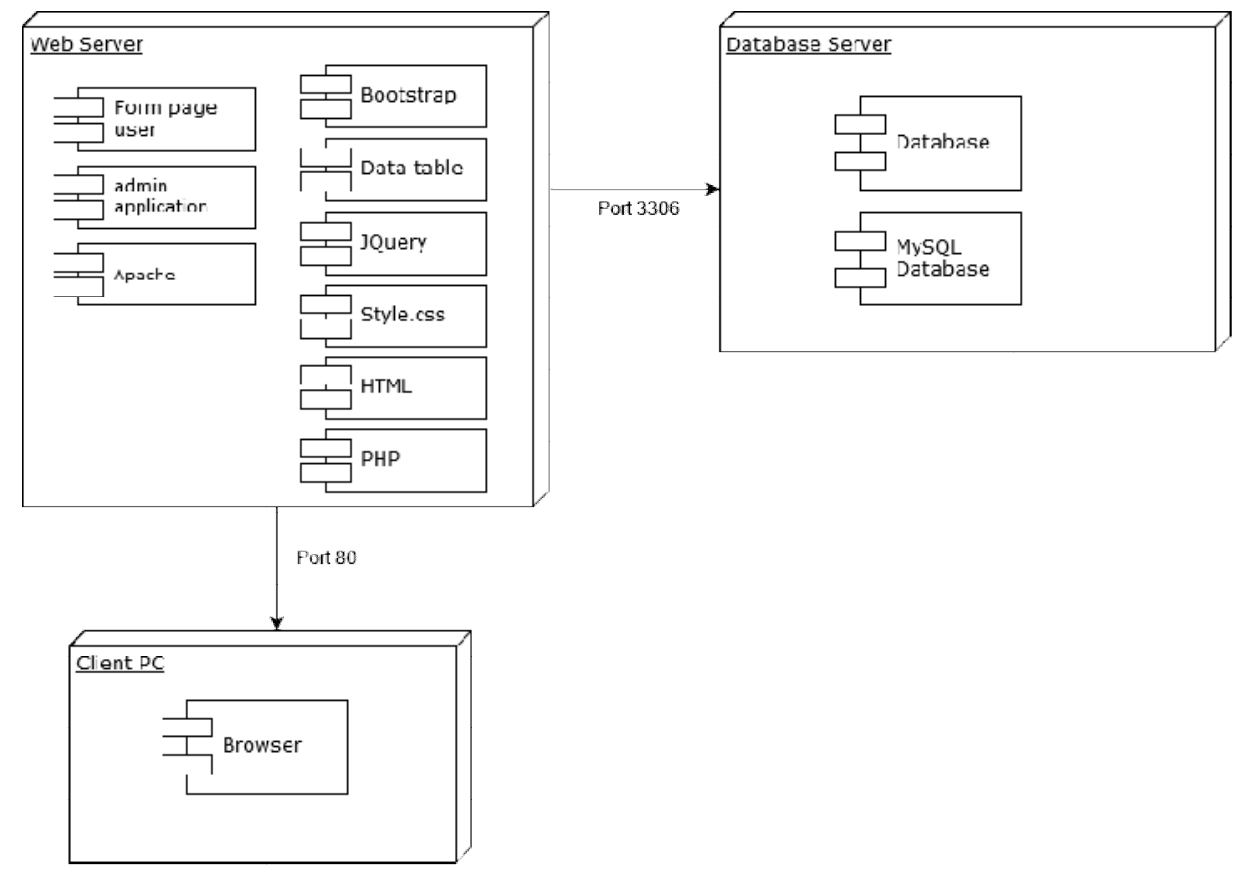

Gambar 4.12 Deployment Diagram

\subsubsection{Class Diagram}

Class diagram digunakan untuk menampilkan beberapa kelas yang berada dalam sistem perangkat lunak yang akan dikembangkan. Class diagram menunjukan hubungan antar class dalam sistem yang dibangun dan bagaimana saling berkolaborasi untuk mencapai tujuan. Berikut gambaran class diagram dari Sistem Jadwal Pelatihan Karyawan pada PT.XYZ :

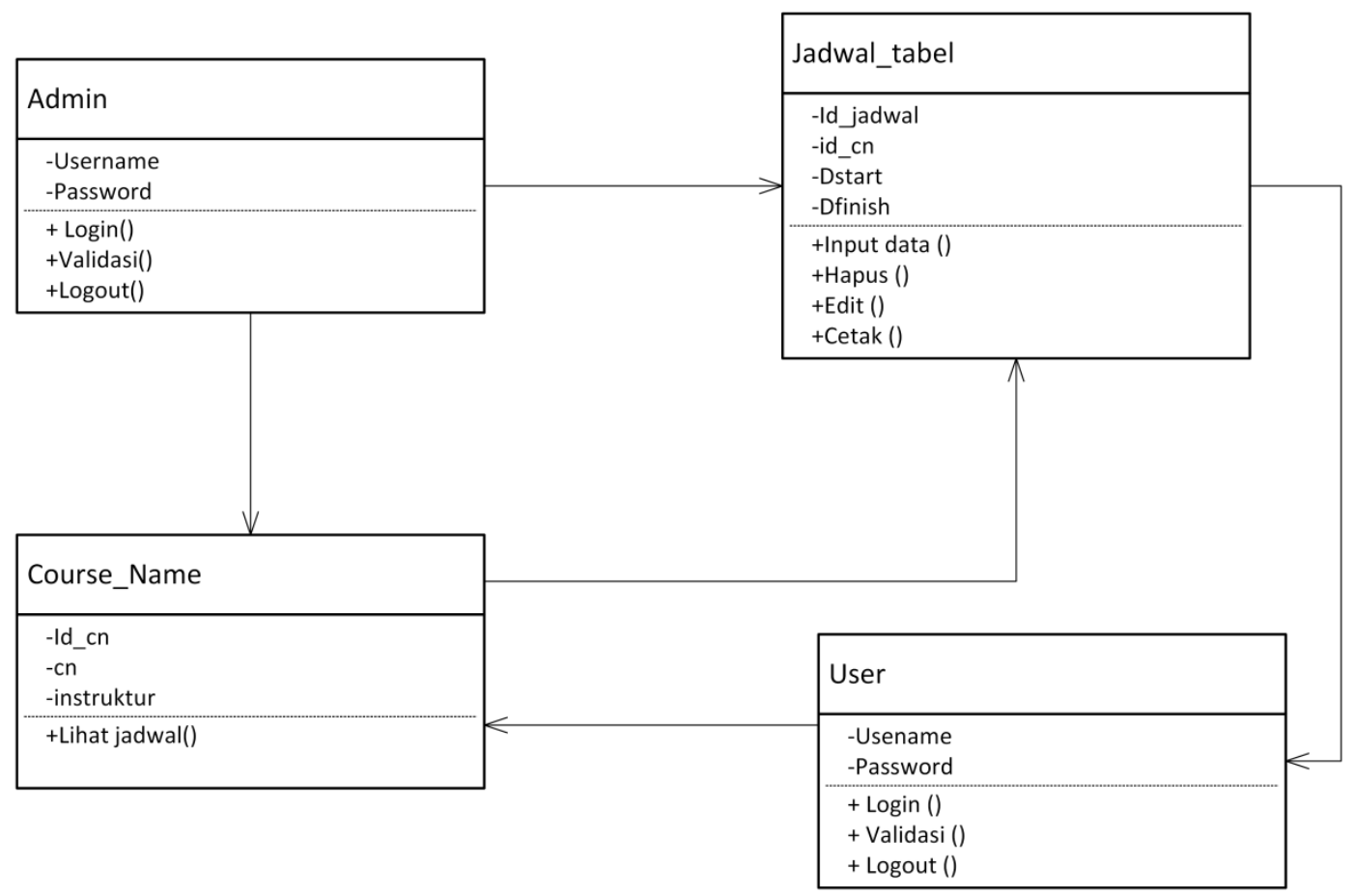

Gambar 4.13 Class Diagram 


\subsection{Desain Input dan Output}

Desain input dan output digunakan sebagai acuan dalam merancang dan membangun sistem berupa form masukan data dan laporan sebagai informasi yang dihasilkan dari pengolahan data.

\subsubsection{Input}

Desain input digunakan sebagai perancangan desain masukan dari pengguna pada sistem yang kemudian akan disimpan dalam database.

\section{A. Login}

Desain input login digunakan sebagai gerbang masuk ke dalam sistem input jadwal pelatihan. Pengguna memasukan username dan password yang dimilikinya.

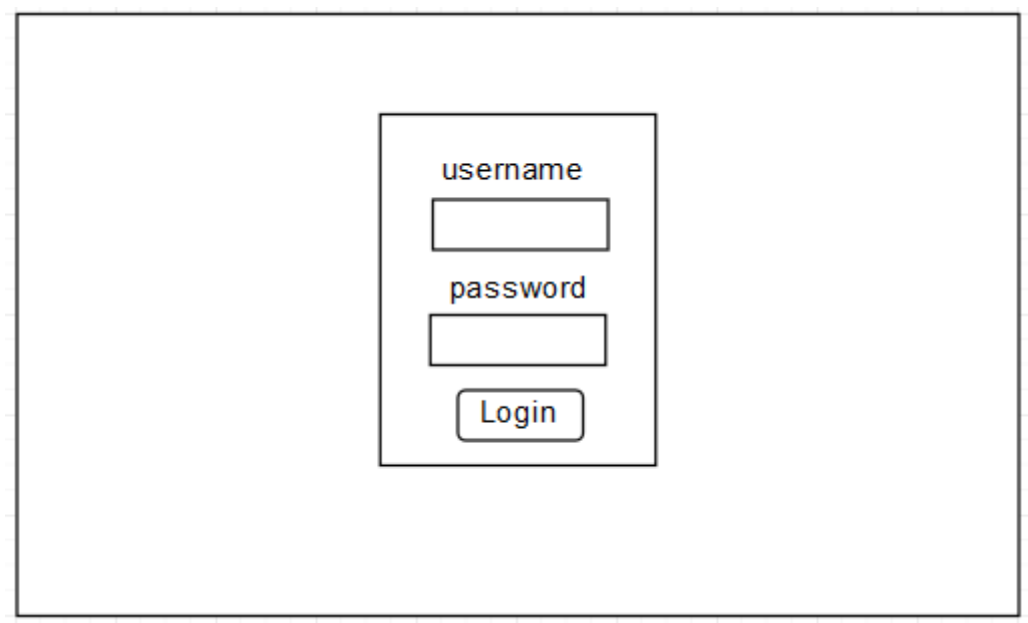

Gambar 4.14 Desain Login

\section{B. Form Input Data}

Data input ini digunakan untuk menginputkan data jadwal sebelum dikirimkan. Admin sebagai pengguna harus memasukan Course Name, Start
Date, End Date, dan Place. Button submit digunakan untuk menyimpan ddata ke database dan akan membuka tampilan tabel jadwal.

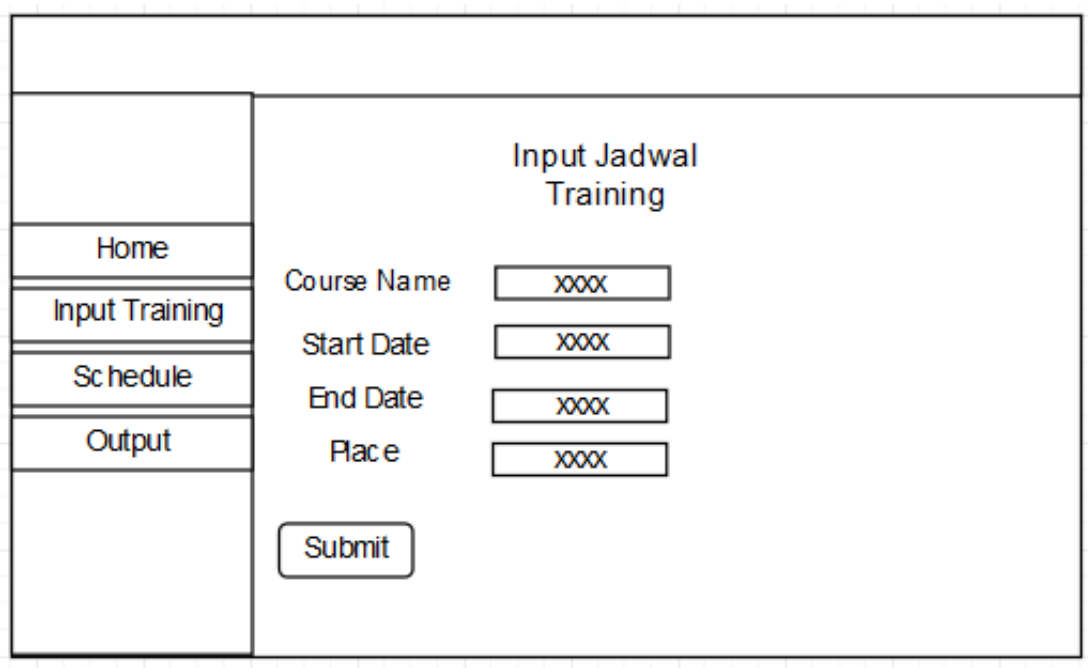

Gambar 4.15 Desain Form Input 


\subsubsection{Perancangan Pesan}

Perancangan pesan diperlukan untuk memberikan konfirmasi sebelum melakukan manipulasi data. Berikut form perancangannya.

A. Logout

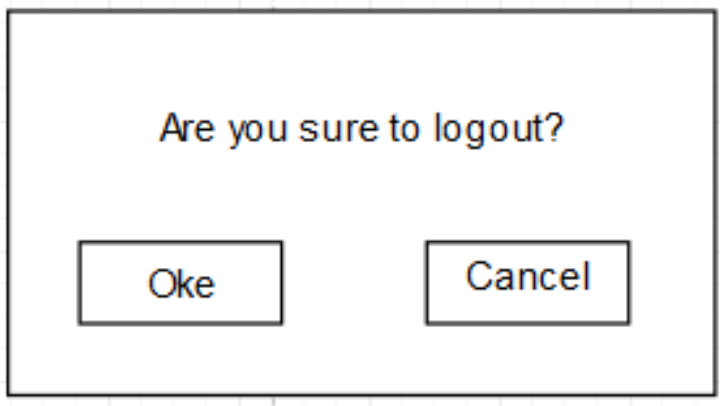

Gambar 4.16 Desain Pesan Logout

B. Hapus

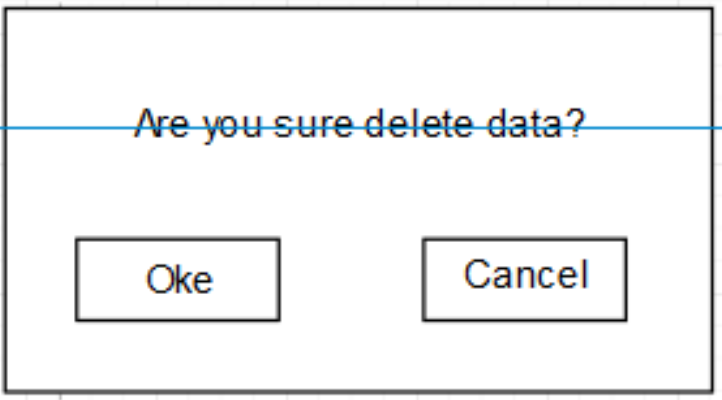

Gambar 4.17 Desain Pesan Hapus

C. Edit

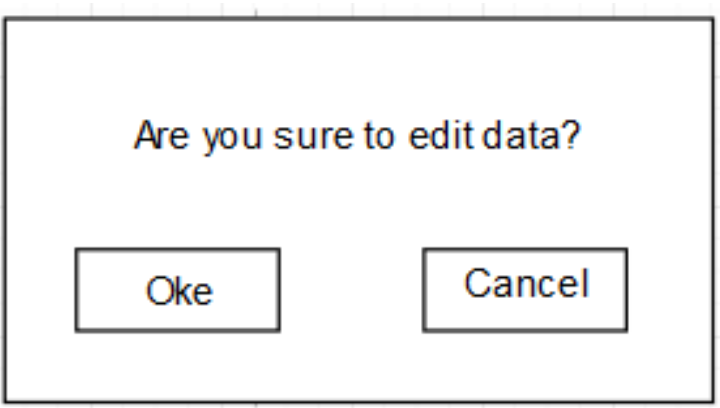

Gambar 4.18 Desain Pesan Edit

\subsubsection{Output}

Perancangan output diperlukan untuk menentukan tampilan program yang berfungsi sebagai tempat menampilkan informasi dan data yang telah di input. Dari hasil sistem ini output yang di hasilkan berupa tampilan tabel jadwal. Button print digunakan untuk cetak jadwal sekaligus menyimpan jadwal. 


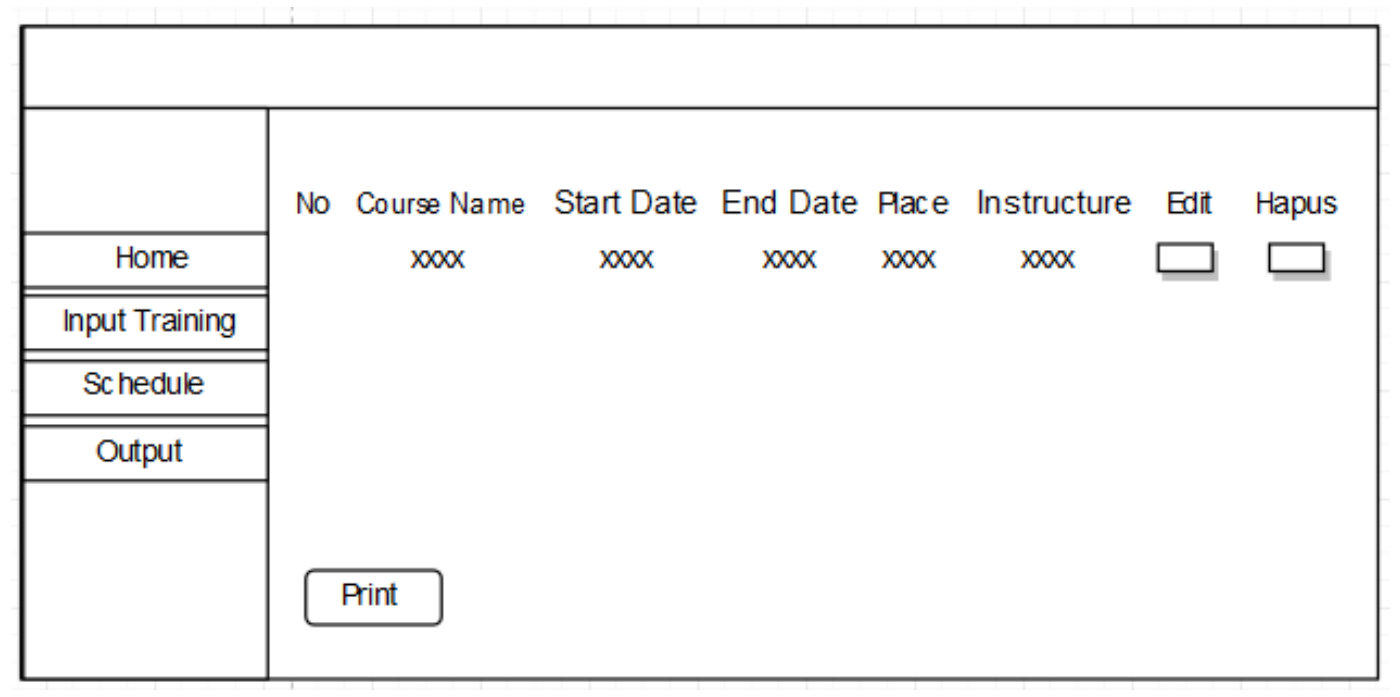

Desain 4.19 Desain Tampilan Laporan

\section{Kesimpulan dan saran}

\subsection{Kesimpulan}

Berdasarkan hasil penelitian penulis yang berjudul Perancangan Sistem Informasi Jadwal Pelatihan Karyawan maka dapat disimpulkan sebagai berikut:

1. Dengan adanya sistem jadwal pelatihan dapat memudahkan admin dalam memasukan data dengan tidak perlu mengetik secara manual dan dapat mencetak laporan data.

2. Sistem jadwal pelatihan ini memiliki penyimpanan data yang sudah terkomputerisasi dan dapat mempermudah admin dalam proses penyimpanan jadwal pelatihan.

\subsection{Saran}

Berikut merupakan saran berdasarkan aplikasi yang telah di buat:

1. Membuat batas terhadap pihak yang berhak mengakses informasi jadwal pelatihan.

2. Untuk penelitian berikutnya sistem dapat di kembangkan secara generate, dimana data yang ada dapat disusun menggunakan Algoritma Genetik sebagai metode sistem.

\section{DAFTAR PUSTAKA}

[1] Anhar. 2010. Panduan Menguasai PHP \& MySQL. Jakarta: Media Kita.

[2] Arief, M. Rudyanto. 2011. Pemrograman Web Dinamis menggunakan PHP dan MySQL. Yogyakarta: Andi Publisher.

[3] Aditya, Alan Nur. 2011. Jago PHP dan MySQL. Bekasi: DUNIA KOMPUTER.

[4] AMIK YMI. 2012. Pelatihan Desain Web dengan Adobe Dreamweaver CS5. Tegal.

[5] Daryanto, 2012.Dasar Pemrograman Web PHP-MYSQL dengan Dreamweaver.ITB: Bandung.

[6] Hidayat, Rahmat. 2010. Cara Praktis Membangun Website Gratis. Jakarta: PT Elex Media Komputindo.

[7] Hidayat, Taufik. 2008. Panduan Membuat Toko Online dengan OSCommerce. Jakarta: Mediakita. 
[8] Kusrini. 2007. Strategi Perancangan dan Pengelolaan Basis Data. Yogyakarta: CV ANDI.

[9] Purnomo, V. P. 2005. Cara Mudah Membuat Website Dengan Dreamweaver MX. Jakarta: Dian Rakyat.

[10] Setiawan, (2013).Pemrograman Web dengan HTML. Bandung :Informatika.

[11] Suyanto, Asep Herman. 2008. Step by Step Web Design Theory and Practice Edisi II. Yogyakarta: Andi Publisher. 
